\title{
Литературное наследие С. К. Тока в фондах Национального архива Республики Тыва
}

\author{
Евгений Д. Монгуш \\ Тувинский государственный университет, Российская Федерация
}

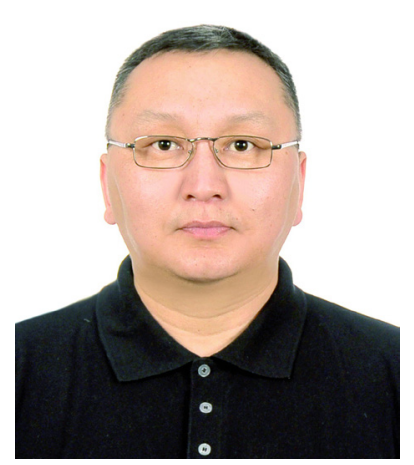

Литературное наследие тувинского общественно-политического деятеля и писателя Салчака Калбакхорековича Тока представлено в нескольких архивах Тувы. В статье разбирается состав и содержание небольшой, но малоизвестной, ценной коллекции рукописей произведений (11 ед.) из фондов Национального (до 07.04.2020 г. - Государственного) архива Республики Тыва. Многие отрывки рукописей существенно разнятся с изданными текстами и этот аспект творческой эволюции писателя рассматривается впервые.

Например, в фондах имеется рукопись рассказа «Охота на волков» (март 1947 г.). Он был опубликован на русском языке в сборнике в 1967 г. и содержит отхождения от оригинала: были изменены имя главного героя и род деятельности второстепенного, но важного героя. В процессе творческой работы Тока мы видим определенное «свертывание» текста.

Автобиографический роман-трилогия С. К. Тока «Слово арата» издавался частями, разными версиями с 1932 г., в 1940-е г2., с названием «Слово арата»-на русском языке в 1950 г., несколько первых изданий в 1951 и 1964 г2.; на тувинском языке - в 1967 г. Далее он неоднократно переиздавался. В архиве представлены варианты рукописей отрывков. Сравнительный анализ показал переработки, дополнения, а также сокращения. Рукописный текст более богат лексикой, подробностями, описаниями; содержит меньше идеологических штампов.

Сопоставление архивных рукописей и изданий позволяет проследить историю создания произведений, а также изменения в творческих приемах писателя, в эволюции его творчества; почувствовать часто ускользающие при чтении тончайшие нюансы, столь необходимые для объективной интерпретации авторского текста.

Ключевые слова: Государственный архив Республики Тыва; Национальный архив Республики Тыва; Тува; Салчак Калбакхорекович Тока; тувинская литература

Для цитирования:

Монгуш Е. Д. Литературное наследие С. К. Тока в фондах Национального архива Республики Тыва // Новые исследования Тувы. 2020, № 2. C. 175-186. DOI: www.doi.org/10.25178/nit.2020.2.12

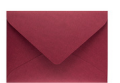

Монгуш Евгений Докурович - кандидат филологических наук, доцент кафедры русского языка и литературы Тувинского государственного университета. Адрес: 667000, Россия, г. Кызыл, ул. Ленина, д. 36. Тел.: +7 (960) 778-47-98. Эл. адрес: mongun2005@yandex.ru

ORCID ID: 0000-0002-4202-3011

Mongush Eugeny Dokurovich, Candidate of Philology, Associate Professor, Department of the Russian Language and Literature, Tuvan State University. Postal address: 36 Lenin St., 667000 Kyzyl, Russian Federation. Tel.: +7 (960) $778-$ 47-98. E-mail: mongun2005@yandex.ru 


\title{
S. K. Toka's literary heritage in the collections of the National Archives of the Republic of Tuva
}

\author{
Evgeny D. Mongush \\ Tuvan State University, Russian Federation
}

The literary heritage of Tuvan public and political figure, writer Salchak Kalbakhorekovich Toka is preserved at Tuva's several archival institutions. This article deals with a small and relatively little known fond of manuscript versions (11 archival units) preserved at the National Archives (prior to 07.04.2020 known as the State Archives) of the Republic of Tuva. Many fragments in these manuscripts radically differ from the later text in the printed version, which is important for studying the author's evolution.

The collection, for instance, contains the manuscript version of the short story "Wolf hunt" (1947). It was published in a collection in Russian in 1967, with important digressions from the Tuvan original: the protagonist now had a different name, and one of the supporting (but important) characters had had his occupation changed. As Toka was working in the text, the feelings became less expressive.

S.K. Toka's autobiographical trilogy "The word of the arat" was published in various versions, part by part, starting from 1932, and into the 1940s. As "The word of the arat", it appeared in Russian in 1950, with some first editions in 1951 and 1964, and in Tuvan, in 1967. Both versions were many times reprinted. A comparative study of the fragments in the archival collection has revealed a number of cuts, additions and reworkings, with the manuscript version richer in vocabulary, minor details, descriptions and containing fewer ideological clichés.

Comparing archival manuscripts and printed editions helps us trace the history of a literary text and sense changes in the author's creative techniques, in evolution of his art. We can feel the minutest nuances of his work, which are so important for providing an objective interpretation of the author's text - and yet are so fleeting and easy to neglect.

Keywords: State Archives of the Republic of Tuva; National Archives of the Republic of Tuva; Tuva; Salchak Kalbakhorekovich Toka; Tuvan literature

\section{Введение}

Литературное наследие Салчака Калбакхорековича Тока ${ }^{1}$ представлено в фонде 50 Национального архива Республики Тыва (Государственного архива Республики Тыва, ГА РТ) ${ }^{2}$ и в нем хранятся более 150 ед. хр. Из них 11 единиц хранения - это рукопись пьесы «Үүр даргазынга үш чыл болдум» («Три года на посту председателя партийной ячейки»), переименованная затем в «Тонгур-оол» (1937), рукопись повести «В берестяном чуме» (1957), рукопись рассказа «Охота на волков» (1947), публикации отрывка очерка «Маадыр ие» («Мать-героиня») в газете «Шын» 12.05 .1959 г., а также рукопись очерков о МонгунТайге (1958), о Туве (1964) и рукопись воспоминаний (напечатано на машине) к главе «Шушенское» (1969) романа «Слово арата».

\footnotetext{
${ }^{1}$ Тока Салчак Калбакхорекович (1901-1973) - тувинский советский государственный деятель и писатель. Лауреат Сталинской и Государственной премий за роман «Слово арата» (1950). Генеральный секретарь ЦК Тувинской народно-революционной партии (1932-1944); первый секретарь Областного комитета ВКП(б) Тувинской автономной области (1944-1952); первый секретарь Областного комитета КПСС Тувинской автономной области (1952-1961), первый секретарь Тувинского областного комитета КПСС (1961-1973).

${ }^{2}$ В связи с тем, что переименование архива пришлось на период предпечатной подготовки статьи (7 апреля 2020 г.) далее мы сохраняем в тексте старое название «Государственный архив Республики Тыва» и аббревиатуру «ГА РТ». - ped.

Editors' note: Since the Archives was renamed while editorial work on the article was already under way (April 7, 2020), we have preserved at some places the institution's old name - "State Archives of the Republic of Tuva".
} 
Надо сказать, что материалы, относящиеся к литературному наследию С. К. Тока, хранятся также и в фондах Научного архива Тувинского института гуманитарных и прикладных социальноэкономических исследований при Правительстве Республики Тыва (НА ТИГПИ, ф. 2248). Это вырезки из газет «Шын» и «Тувинская правда» за 1955 г. (6 шт.) в рукописном фонде (РФ НА ТИГПИ, ф. 2248, д. 1, л. 16), трилогии (газетных публикаций 2-й книги, вышедшей в 1955 г.) «Слово арата» (РФ НА ТИГПИ, ф. 2248), рукописи на тувинском языке разных частей трилогии «Слово арата» (РФ НА ТИГПИ, дд. 3-12).

Несмотря на небольшое количество текстов, рукописи Тока представляют достаточно ценную коллекцию (ГА РТ, ф. 50, 153 ед. хр.). В ней представлены различные жанры прозы: роман, повесть, очерк, рассказ, а также драма и газетная публикация. В них содержатся факты, которые могут обогатить, уточнить, а возможно и пересмотреть существующие представления о Тока-писателе, о его жизненной, творческой судьбе. Коллекция государственного архива по сравнению с Научным архивом ТИГПИ представляется более полной и разнообразной. О том, что в фондах ГА РТ представлена и хранится большая коллекция рукописей, относящая к литературному наследию С. К. Тока, известно многим исследователям, но данная коллекция до сегодняшнего дня специально не изучалась. Известна только публикация Д. У. Чамзо, в которой рассмотрено содержание всего фонда Тока (Чамзо, 2018).

Обзор рукописей художественных произведений С.К. Тока из фонда 50 ГА РТ, представленный в данной статье, преследует сугубо конкретную цель: ввести этот материал в научный оборот, дать общую характеристику литературным рукописям по жанрам.

Уже на этом, первом, этапе знакомства с рукописями, можно выделить ряд важных особенностей как частного, так и общего характера в его работе над текстами различных произведений. Многие отрывки рукописей существенно разнятся с изданными текстами известных произведений С. Тока (роман «Слово арата», рассказ «Охота на волков»). В наши задачи входит обзор материалов, их характеристика и разбор отдельных рукописей: пьесы «Үүр даргазынга үш чыл болдум» («Тонгур-оол»), рассказа «Охота на волков», очерков и романа «Слово арата». Этот аспект творческой эволюции писателя рассматривается впервые.

\section{Пьеса «Үүр даргазынга үи чыл болдум» («Тонгур-оол») 1937 2.}

В партийном фонде 347, опись 1, ед. хр. 1. Государственного архива Республики Тыва, в личном листке по учету кадров Салчака Калбакхорековича Тока есть запись, выполненная каллиграфическим почерком самим С. Тока: «... «Родился 15.12.1901 в местечке Мерген Каа-Хемского района, в партии состоит с 1929 года, владеет русским и монгольским языками, окончил КУТВ в Москве в 1929 году, по специальности политработник» (ГА РТ, ф.п.-347, оп. 1, д. 1, л. 1). Там же в учетной карточке писателя стоит дата вступления в Союз писателей СССР 17 апреля 1957 г. (там же: л. 3). В личной карточке члена Союза писателей СССР в графе 7 «литературный жанр» - прозаик, слово «драматург» собственноручно зачеркнуто (там же: л. 8).

Тем не менее, С. К. Тока относится к той плеяде тувинских писателей, которые первыми начали в 1930-е годы пробовать себя в жанре драмы. Первые тувинские пьесы «Чечен-кыс», «Ханский закон» были написаны С. Сарыг-оолом, Б. Ховенмеем, М. Кызыл-оолом в 1920-е годы. А первые авторские пьесы на тувинском языке стали выходить отдельными изданиями только в 1930-е годы (Кужугет, 2015: 400). С. К. Тока является автором первых авторских пьес в тувинской литературе: «Херээжен» (Женщина) (1935), «Узун-Кара, Семис-Кара» (1937).

Пьеса «Үүр даргазынга үш чыл болдум» («Три года на посту управляющего арбаном») («Тонгур-оол»), датируется 1937 г., опубликована в г. Кызыле в 1938 г. в Тувинском книжном издательстве'. Данная пьеса является одной из первых тувинских авторских драматических произведений, она не потеряла своей актуальности и сегодня. Впервые в тувинской литературе в образе Тонгур-оола читатель видит «провинившегося» в своих поступках чиновника. В пьесе поставлены злободневные проблемы и вопросы, актуальные для молодой республики в 1920-1930-е годы: борьба с безграмотностью, невежеством и т. д. Произведение можно рассматривать как образец литературного наследия тувинского народа, в котором отражены художественные и культурные традиции периода Тувинской народной республики.

\footnotetext{
${ }^{1}$ Тока, С. К. (1938) Үүр даргазынга үш чыл болдум: шии. Кызыл : ТывНҮЧ. 33 ap.
} 
Пьеса является комедией из 3-х действий, основной сюжет которой разворачивается вокруг классовой борьбы в 1920-1930-е годы. Общественно-политическая ситуация в новом государстве Тувинской Народной Республике (1921-1944 гг.) - была напряженной. Главный герой комедии - Тонгур-оол, чиновник среднего звена, все время сомневается и заблуждается в своей правоте в той или иной ситуации.

Рукопись пьесы в рассматриваемом нами фонде написана самим автором на основе латинского алфавита и насчитывает 42 листа (ГА РТ, ф.П.-50, оп. 1, д. 1, л. 1-42). Она уже входила в поле внимание исследователей. Так, например, Д. У. Чамзо пишет, что видное место в личном фонде С. К. Тока занимают рукописи его рассказов, очерков, статей и других произведений: «Имеются, например, рукопись пьесы “Үүр даргазынга үш чыл болдум" (Три года на посту управляющего арбаном), датированной 1938 г., которая впоследствии стала называться “Тонгур-оол” (Чамзо, 2018: 85). Правда, Д. У. Чамзо ошибочно указывает на 1938 г. В самой рукописи стоит 1937 г.

К сегодняшнему дню в тувинской литературе вполне подробно изучены те обстоятельства, которые сопутствовали литературной и сценической жизни этой пьесы, выявлены основные оценки критиков (Калзан, 1958: 115-136; Кужугет, 2015: 400). Однако, рукопись пьесы, как пишет А. Херел, не изучена исследователями (Херел, 2018: 10). Расхождений с рукописью нет, только у пьесы изменилось название.

\section{Рассказ «Охота на волков» 1947 г.}

С. К. Тока много работал с публицистическими жанрами: он писал документальные рассказы, документальную повесть, очерки, репортажи, путевые заметки (Донгак, 2015: 373). Известно также о том, что он вел дневники своих дел и встреч, записи делал на русском языке (см.: Ширшин, 2017). В фондах Государственного архива Республики Тыва имеются рукописи Салчака Тока, написанные в малых прозаических жанрах: рассказ, повесть, очерк.

В партийном фонде 50-1-6 имеется рукопись рассказа «Охота на волков» (на русском языке, видимо перевод, но имя переводчика не указано) и напечатанная на машинке на 8 листах, датированная мартом 1947 г. (ГА РТ, ф.п.-50, оп. 1, д. 6, л. 1-8). Исследователь тувинской литературы В. Салчак дал литературоведческий анализ самого рассказа «Охота на волков», где указывает, что данный рассказ имеет большую культурную ценность, входит в число первых тувинских авторских рассказов и отличается своеобразной художественной самобытностью (Салчак, 2010: 48).

Рассказ начинается следующим образом: «Во время одной из поездок по Туве я встретился в пути со знатным скотоводом Иргитом Тарачи. Мне запомнился один его особенный рассказ. Позволь, читатель, передать его тебе» (там же: л. 1). Рассказ был опубликован на русском языке в сборнике очерков и статей «Обновление», изданном в Тувинском книжном издательстве в 1967 г. ${ }^{1}$ В этом издании начало рассказа было переделано до неузнаваемости: «В одну из поездок по Туве встретил я знатного скотовода Чамьяна. Уже тогда слава о нем, как о замечательном охотнике, получившем первую премию за уничтожение волков, распространилась далеко за пределы колхоза» (Тока, 1967: 253). Скорее всего переделка была осуществлена самим автором, так как автор в 1967 г. был первым секретарем Тувинского обкома КПСС, лично контролировал выход своих изданий. Во-первых, в рассказе фигурирует уже другой персонаж по имени Чамьян и в собрании сочинений С. К. Токи 1976 г. (I том) вместо Иргит Тарачи действующим лицом является Кыргыс Чамьян2 . Во-вторых, в рукописном варианте и опубликованном тексте только имя удалого охотника Улур-Херел (одного из второстепенных героев рассказа, вокруг которого разворачивается незамысловатый сюжет) остается неизменным: «Мой собеседник, знаменитый охотник истребитель волков Улур-Херел насмешливо глянул на меня» (ГА РТ, ф.П.-50, оп. 1, д. 6, л. 2): «Выпив чай и закусив, мой собеседник - это был Улур-Херел - насмешливо взглянул на меня» (Тока, 1967: 256).

Род деятельности Улур-Херела в рукописи 1947 г. был определен следующим образом: «Так однажды со знаменитым охотником Херелом начальником районного отдела МГБ, мы застрелили трех синеглазых, не сходя с места. Возвращаясь домой, довольный большой удачей, я про себя подумал: “Хорошие ребята эти чекисты, всегда они на страже интересов народа, в этом смысл их жизни” (ГА

${ }^{1}$ Тока, С. К. (1967) Араттың сөзү. 1-ги ном: тоожу / ред. Ю. Кюнзегеш, Э. Кужугет. Кызыл: ТывНҮЧ. 132 ар. C. 253-261.

${ }^{2}$ Тока, С. К. (1976) Бөрүлерни аңнаары // Тока С. К. Собрание сочинений: в 2 т. Кызыл : Тувинское книжное издательство. Т. 1.328 с. С. 9-18. 
РТ, ф.п.-50, оп. 1, д. 6, л. 8). А в издании 1967 г. Улур-Херел не имеет никакого отношения к чекистам: «Возвращаясь домой, довольный крупной удачей, богатой по результатам охотой, а еще больше полученным уроком, я думал: “Научусь охотиться так, как Херел, и буду охранять стадо от волков”. Я понял, что Улур-Херел специально взял меня на охоту, чтобы научить охранять колхозное добро» (Тока, 1967: 261).

Таким образом, рукопись С. Тока в издании 1967 г. содержит отхождения от оригинала: были изменены имя главного героя и род деятельности второстепенного, но очень «важного» героя - УлурХерела. Данное издание относится к прижизненным изданиям С. Тока. Этот факт означает, что сам автор внес изменения в рассказ, уже не демонстрирует смелость и отважность чекистов, т. е. работников органов государственной безопасности. В рукописи Улур-Херел является работником органов госбезопасности (КГБ).

Рассказ «Охота на волков» впервые был опубликован в альманахе «Улуг-Хем» на тувинском языке ${ }^{1}$, русский перевод был осуществлен и напечатан в 1948 г. в газете «Тувинская правда»², затем выходит в сборнике «Обновление» 1967 г. ${ }^{3}$

Весь этот материал представляет уникальную ценность не только для уяснения первоначального замысла рассказа, его композиции, процесса творческой работы Тока, который отличался определенным «свертыванием» текста. Немаловажное значение приобретает и содержание рукописи, позволяющих в наиболее широком виде представить масштабы «переделки»его персонажей (изменение имен персонажей и их роли в самом тексте).

\section{Очерки 1958-1964 22.}

Салчак Калбакхорекович Тока был мастером многочисленных очерков. Его очерки 1958-1964 гг. интересны в двух отношениях. Во-первых, они отражают историю Тувы 1950-1960-х годов, когда по всей республике проводились коллективизация, массовый переход аратов к оседлой жизни. Во-вторых, С. Тока является не только автором художественной прозы и драматургии, но и документальной прозы.

Партийный фонд 50-1-100 представлен очерком автора о Монгун-Тайге 1958 г. на тувинском языке на 43 листах, напечатано на машинке (ГА РТ, ф.п.-50, оп. 1, д. 100, л. 1-43). Очерк не был опубликован.

Как депутат Верховного Совета СССР С. К. Тока посетил села Монгун-Тайги с депутатской инспекцией. Очерк состоит из трех частей: «Монгун-Тайга», «Кызыл-Хая», «Эртемнин дулгууру» («Ключ знаний»). В ходе поездки Тока посещает не только органы местного самоуправления, но и знакомится с жизнью простых аратов. Из текста рукописи можно узнать информацию о том, что в восьмилетней школе села Кызыл-Хая остро стоит вопрос преподавания предметов на русском языке и педагоги просят разрешить данную проблему. В целом, депутат остался удовлетворенным поездкой в Монгун-Тайгу.

В партийном фонде 50-1-16 хранится текст отрывка очерка «Маадыр-ие» («Мать-героиня») (на тувинском языке), опубликованный в газете «Шын» 12.05 .1959 г. (ГА РТ, ф.п.-50, оп. 1, д. 16, л. 1). Очерк был полностью опубликован в I томе собрания сочинений 1976 г. на тувинском языке4.

За годы советской власти жизнь сельчан изменилась в лучшую сторону. Примером улучшения жизни сельчан является дом арата Кызыл-оола Шаравии: «Шаравии Кызыл-оолдун чурттаар бажыны коорге шында-ла онза. Даштын агыртыр чугайлаан, кырлайтыр серилээн, кудумчуже корген ийи сонганын баарын дилген штакетниктен кажалааш, когертир будаан» («Когда видишь дом Шаравии Кызылоола - глаз радует. Снаружи побелен белой известкой, крыша аккуратно покрыта, перед двумя окнами, которые выходят на улицу, стоит палисадник из штакетников, окрашенный синей краской») (там же: л. 1 ; перевод мой. - E. M.).

В партийном фонде 50-1-47 мы также находим рукопись «Яркий свет Ильича над Тувой» на 26 листах 1964 г. (подзаголовок - «Очерки о Туве» на русском языке (ГА РТ, ф.п.-50, оп. 1, д. 47, л. 1-47). Данный очерк посвящен 20-летию присоединения ТНР к Советскому Союзу: «11 октября особо радостная дата для тувинского народа. 20 лет тому назад в этот день осуществилась исконная его мечта:

\footnotetext{
${ }^{1}$ Тока, С. К. (1947) Бөрүлерни аңнаары: чечен чугаа // Улуг-Хем. № 2. Ар. 51-58.

${ }^{2}$ Тока, С. К. (1948) Охота на волков: рассказ // Тувинская правда. 30 мая. Ар. 4.

${ }^{3}$ Тока, С. К. (1967b) Обновление. Очерки, статьи. Кызыл: Тувинское книжное издательство. 261 с.

${ }^{4}$ Тока, С. К. (1976) Маадыр-ие // Тока С. К. Собрание сочинений: в 2 т. Кызыл : Тувинское книжное издательство.

Т. 1.328 с. С. 107-120. (На тув. яз.).
} 
быть, трудиться и радоваться плодами труда в единой сплоченной семье народов Советского Союза и великого русского народа» (там же: л. 1). В тексте Салчак Тока выражает благодарность от тувинского народа советскому народу, отмечая 20-летие Советской Тувы и 50-летие вхождения Тувы в состав российского государства Правительству Советского Союза и лично товарищу Н. С. Хрущеву. Он также заверяет, что тувинцы будут работать во благо светлого будущего и внесут посильную долю своего труда в великое дело борьбы за торжество коммунизма в нашей стране.

Малые эпические формы представлены в рукописном наследии Салчака Тока небольшой коллекцией. Опубликованные варианты ничем не отличаются от рукописей. Очерки писателя опубликованы в различных изданиях и при жизни, и после смерти автора ${ }^{1}$. Тексты не подвергались трансформации, переделке и переработке. Материалы для своих очерков С. Тока брал из своей профессиональной деятельности. В его личном фонде (хранящемся в партийном фонде ГА РТ), кроме рукописей литературных произведений, имеются и многочисленные тексты докладов и выступлений писателя (Чамзо, 2018: 84). По нашему предположению, некоторые из них легли в основу его очерков. Очерки относятся к документальной прозе - публицистике, поэтому в них неизменным остается художественное время, которое соприкасается прежде всего с существующей реальностью, в нашем случае - с темой построения и формирования социалистического общества в Туве. В сюжетах выражаются довольно узнаваемые случаи или прямо указанные реальные события. Так, в рукописи очерка «Яркий свет Ильича над Тувой» писатель главной темой обозначил 20-летие присоединения ТНР Советскому Союзу.

\section{«Слово арата»: рукописи, тексты, версии}

Роман-трилогия С. К. Тока «Слово арата» по своей художественной структуре примыкает к романам автобиографическим. Трилогия состоит из трех книг. Первая книга была издана в 1932 г. на латинице под названием «Kincini casa şapkanь» («Оковы разбиты») в виде автобиографического очерка (см.: Комбу, 2012). Затем в 1941 г. автор издал его под названием «Meen saktьsşkьnьm» («Moe воспоминание»)2. В 1944 г. уже издал под другим названием «Тос чадырда» («В берестяном чуме») Салчак Тока определил как повесть в издании 1951 г., вышедшего в издательстве «Советский писатель» . В 1950 г. в журнале «Сибирские огни» была опубликована первая часть автобиографического романа С. К. Токи «Слово арата» под заглавием «К большому порогу»5.

«Слово арата» как окончательное название произведения появилось в 1950 г., именно под таким названием оно вышла в издательстве «Советский писатель». Самым «урожайным» стал 1951 г. Одновременно произведение было выпущено издательствами: Тувинским областным, московским «Госполитиздатом» и новосибирским «Госиздатом». В 1964 г. в Тувинском книжном издательстве вышла третья книга «Слово арата» под названием «Чаа Тыва» («Новая Тува»)

На тувинском языке в 1967 г. была издана первая книга «Слово арата», и в этом же году она была переиздана. На титульном листе издания жанр произведения уже обозначился как роман ${ }^{7}$ Роман издавался неоднократно в 1970, 1972 гг. в Тувинском книжном издательстве. С 1972 по 1988 гг. во многих издательствах СССР «Слово арата» переиздавался как роман-трилогия (Комбу, 2012: 160).

В партийном фонде 50-1-14 представлена рукопись повести С. К. Тока «В берестяном чуме», напечатанная на машинке на русском языке на 30 листах, датированная 11 декабря 1957 г. (ГА РТ, ф.п.-50, оп. 1, д. 14, л. 1-30). Это хронологически первый документ по этому роману.

Повесть начинается с обращения к читателю: «Здравствуй, читатель. Какой бы ни была твоя жизнь, я уверен, что ты не откажешься познакомиться с моей родной Мерген» (там же: л. 1). Впервые повесть была напечатана в русском переводе под названием «Слово арата» в издательстве «Советский писатель»

${ }^{1}$ Тока, С. К. (1959) Маадыр ие: очерк Ш. Кызыл-оол из колхоза «Көк-Чыраа» // Улуг-Хем. №15. Ар. 180-185; Тока, С. К. (1979) «Мезилчигеш» суур: очерк // Шын. Апрель 7. Ар. 4.

${ }^{2}$ Тока, С. К. (1941) Meen saktььşkьnьт. Кьzьl : ТывНҮЧ. 60 ар.

${ }^{3}$ Тока, С. К. (1944) Тос чадырда. Кызыл : Тывкүрпарлалга. 66 ар.

${ }^{4}$ Тока, С. К. (1951) Слово арата: повесть. М. : Советский писатель. 151 с.

${ }^{5}$ Тока, С. К. (1950) К большому порогу // Сибирские огни. № 2. С. 5-77. См.: Красильникова, Вальдман, $2020: 159$.

${ }^{6}$ Тока, С. К. (1964) Чаа Тыва. Үшку ном Кызыл: Тываның ном үндүрер чери. 462 с. (На тув. яз.). См. также: Комбу, 2012: 160 .

${ }^{7}$ Тока, С. К. (1967) Араттың сөзү. 1-ги ном: тоожу / ред. Ю. Кюнзегеш, Э. Кужугет. Кызыл: ТывНҮЧ. 132 ар. См. также: Комбу, 2012: 160. 
в Москве в 1951 г. в авторизованном переводе с тувинского А. Тэмира (А. Тэмир - литературный псевдоним А. А. Пальмбаха, филолога, тюрколога, одного из создателей тувинского алфавита на основе кириллицы) и тоже начинается с обращения к читателю: «Здравствуй, читатель! В каком бы краю нашей великой страны ты ни был и какой бы ни была твоя трудовая жизнь, я уверен - ты не откажешься познакомиться с моей родной Мерген» (Тока, 1951: 5). Повесть состоит из 3 частей: «В берестяном чуме», «Где счастье», «Борьба началась».

Первая часть заканчивается размышлениями маленького Токи о своей судьбе и здесь мы не видим никаких расхождений и текстовых изменений первоначального варианта (архивной) рукописи с опубликованной:

«В тот день мне казался удивительно чистым, прекрасным. Я был тогда еще очень мал, чтобы задумываться над тем, почему под этим чистым счастливым небом так горька и беспросветна наша жизнь, так беден и убог наш берестяной чум» (ГА РТ, ф.п.-50, оп. 1, д. 47, л. 30).
«В тот день мир мне казался удивительно чистым, прекрасным.

Я был тогда еще слишком мал, чтобы задумываться над тем, почему под этим чистым счастливым небом так горька и беспросветна наша жизнь, так беден и убог наш берестяной чум» ${ }^{1}$.

Партийный фонд №50-1-44 представлен также рукописью повести «Араттын созү» («Слово арата») на тувинском языке, подлинник на 111 листах. Датирован 1964 годом. Это второй хронологический документ по данному роману, хранящийся в ГА РТ. Каллиграфическим почерком автора до 24-го листа рукопись повести написана от руки, а с листа 25 по 69 отрывок «Четтирдим нам» отпечатана на машинке, с 70 до 111 листа - снова от руки. В тексте много правок от руки. Рукопись имеет своеобразный эпиграф в виде тувинской поговорки «Адазы көрбээни - оглу көөр» («Чего не видел отец - увидит сын»; перевод мой. - E. М.).

Рукопись заканчивается целым абзацем, написанным автором карандашом: «Адактың соонда намның эге организацияларының ниити Хуралындан Түмен хөөнү кандидат кежигүнүнге киирип алган, эш өөрү холдарын туткулаан чоруу чогумчулуг, ажылы бүдүнгүр болурун ийерээн тургулааннар. “авамга, авамга” - деп бодааш Туменхөө хуралдан үне халаан...» («В конце концов от первичных организаций партии на общем собрании Тумен хоо приняли кандидатом, товарищи пожимали ему руки, желали удачи и благополучия в работе. “Матери, матери”, - подумал Тумен хоо, выбежал из собрания...» (ГА РТ, ф.п.-50, оп. 1, д. 44, л. 111; перевод мой. - E. M.).

В партийном фонде 50-1-6, кроме упомянутого выше рассказа «Охота на волков», имеются отрывки из 3-й книги «Слово арата» - «Тува кочующая» 1964 г. (ГА РТ, ф.П.-50, оп. 1, д. 6, л. 9-21)); глава из 3-й книги «Колхоз на Терзиге» 1964 г. (ГА РТ, ф.п.-50, оп. 1, д. 6, л. 21-41); отрывки из 3-ей книги «Тува кочующая» 1964 г. (ГА РТ, ф.П.-50, оп. 1, д. 6, л. 42-54)) и партийном фонде 50-1-45 отрывок главы «Первый водитель» из третьей книги «Тува Новая» повести «Слово арата» 1964 г. (ГА РТ, ф.П.-50, оп. 1, д. 45, л. 1-57). Документы напечатаны на машинке.

Отрывок «Первый водитель» вошел в третью книгу «Здравствуй, Москва», в главу девятую. Для анализа и сравнения мы пользовались изданием 1973 г. ${ }^{1}$

Отрывок был переработан, скорее всего, уже после смерти С. К. Тока (1973). Трилогия вышла в свет в 1973 г. Авторизованный перевод с тувинского А. Тэмира и С. Пюрбю. Так, в авторской рукописи излагается следующий отрывок:

«Никитина - дочь хакаса и русской. Мария Федоровна вышла замуж тоже за хакаса, была в связях с аратами Шагонара и Кожай Торгалыга. Стройная, с овальным лицом и тонким носом, с узкими, вечно игривыми глазами, с черной, собранной в пучок косой, она и в приклонном возрасте была еще красива и приятна веселым характером. Её муж, Никитин, батрачил у баев, с ним и приехал в Туву. Он рано умер, оставив двоих сирот» (ГА РТ, ф.п.-50, оп. 1, д. 45, л. 13).

«Держала это заведение полухакаска-полурусская Мария Федоровна Никитина. Муж её, хакас, батрачил у русских богатеев, с ними приехал в Туву, но вскоре умер, надорвавшись на непосильной работе. Марья Федоровна осталась с двумя дочерьми. Я знал эту женщину» ${ }^{2}$.

${ }^{1}$ Тока, С. К. (1973) Слово арата : роман в 3 кн. М. : Современник. 430 с.

${ }^{2}$ Там же. С. 316. 
В опубликованном тексте в 1973 г. данный отрывок представлен по-иному.

Мы видим, что авторский текст был существенно переработан. В опубликованном тексте наблюдаются идеологические «нотки»: «надорвавшись на непосильной работе», «батрачил у русских богатеев».

Рукописный отрывок «Колхоз на Терзиге» (ГА РТ, ф.п.-50, оп. 1, д. 45, л. 22-41) вошел в двадцать первую главу трилогии «Слово арата». Для сравнения двух текстов была взята начало действия, где идет описание погодных условий:
«Была середина июня. Два дня подряд берега Каа-Хема и его притоков дрожали от громовых ударов и тонули в ливнях. Терзиг выбежал из берегов на обширные поймы и ревел, никому не давая через себя переправиться» (там же: л. 22).
«Два дня над Каа-Хемом и его притоками не умолкали раскаты грома. Два дня лились с неба потоки воды. Терзиг вырвался из берегов и ревел, никого не подпуская к себе» ${ }^{\text {. }}$

Мы видим, что отрывок из рукописи больше по объему и богаче лексикой.

В партийном фонде 50-1-45 из третьей книги «Тува Новая» имеется рукопись главы «Первый водитель» (ГА РТ, ф.П.-50, оп. 1, д. 45, л. 1-57). Повесть, а затем роман «Слово арата» имеют автобиографичную основу. Молодой Тока возвращается в Туву для трудоустройства:

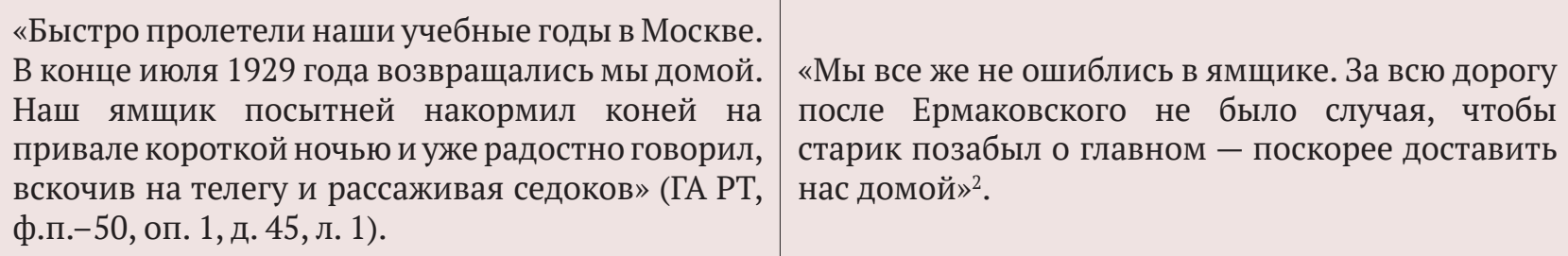

В издании 1973 г. видно, что авторский текст полностью переработан. В новом тексте ни слова о Москве и о времени года - о лете.

В шестую главу также вошел отрывок «Первые шаги». Отрывок из архивного документа, который повествует о начале карьеры Токи (левая колонка):

«В ту ночь я почти не спал, думая, на какую поступлю работу. Вскочил когда красно-бурые лучи утреннего солнца только что выглянули из-за вершины Ондума и начали лизать землю, освещая Доге» (ГА РТ, ф.п.-50, оп. 1, д. 45, л. 17).
«В ту ночь я почти не спал. Все думал и думал, что ждет меня, какую поручат работу, как буду жить... Поднялся я на рассвете, когда солнце только-только выглянуло из-за вершины Ондума и ласково лизнуло землю» ${ }^{3}$.

Рукописный отрывок «В родном аале» (ГА РТ, ф.п.-50, оп. 1, д. 45, л. 29-37) вошел в седьмую главу «В родном аале» книги третьей «Здравствуй, Москва!» Данный отрывок повествует о том, какие испытания ждут молодого выпускника КУТВа ${ }^{4}$ на работе и каким образом образовалась пауза на работе:

«Видя, что на работе меньше дела, чем в отпуску, я выпросился на несколько дней и верхом на коне поехал по уртелям к родным на Каа-Хеме в Терзиг и Мерген» (там же: л. 29).
«А делать было решительно нечего. Видя это, я отпросился на несколько дней и верхом на коне отправился по уртелям - ямским перегонам, на которых можно было менять лошадей, - к родным, в Терзиг и Мерген» ${ }^{5}$.

А в опубликованном тексте нарратор усиливает повествование.

Рукописный отрывок «Оттук-Даш» вошел в восьмую главу третьей книги трилогии и повествует о том, что на работе ждут Току и поручают ему новое задание:

\footnotetext{
${ }^{1}$ Там же. С. 411.

${ }^{2}$ Там же. С. 277.

3 Там же. С. 287.

${ }^{4}$ КУТВ - Коммунистический университет трудящихся Востока.

${ }^{5}$ Тока, С. К. (1973) Слово арата : роман в 3 кн. М. : Современник. 430 с. С. 295.
} 
«Приехав в Кызыл, я сразу вышел на работу. Мой начальник Данчай-оол вызвал меня к себе.

- Ищут тебя из ЦК партии, ступай туда. - Он усмехнулся: - ты только что поступил на работу, а тебя сразу вызывают. Это неспроста» (ГА РТ, ф.п.-50, оп. 1, д. 45, л. 37).

Рукописный текст более богат лексикой, большинство предложений в тексте являются распространенными.

Рукописный отрывок «Удивительное собрание» входит в восьмую главу «Оттук-Даш» (ГА РТ, ф.П.-50, оп. 1, д. 45, л. 44-54). Получив задание, Тока направляется в кожуун для проведения собрания среди партийцев кожууна:

«Мы догоняем двух всадников: араты с перекидными сумами на седле скачут вровень с нами. Санча от души хохочет и кричит:

- Скорей, скорей, ребята!.. Друг! Еще нажми» (там же: л. 44).

В издании 1973 г. вышеуказанное действие расширяет свои горизонты,

Далее в главу «Оттук-Даш» вошла рукопись «Мой доклад», в которой повествуется о том, что главный герой делает отчет о проделанной работе в Улуг-Хеме:

«В Кызыле я прошел прямо к Пюльчуну и доложил о делах в Улуг-Хеме» (ГА РТ, ф.п.-50, оп. 1, д. 45, л. 54).

В опубликованном тексте ни слова об Улуг-Хеме.

Рукописный отрывок «Внутри пламени» из третьей книги романа «Слово арата» (ГА РТ, ф.П.-50, оп. 1, д. 45, л. 137-149) опубликован под названием «Горячая схватка» и представляет главу десятую. В авторской рукописи этот эпизод описывается кратко и сухо.

«Встав пораньше, я пошел к реке Чадан помыться. Взошло солнце. Его лучи и ласкали, и радовали теплом» (ГА РТ, ф.п.-50, оп. 1, Д. 45, л. 137).

«...Проснулся я, едва взошло солнце. Легкий иней быстро сбегал с листьев и травы сверкающими каплями. Галки орали как сумасшедшие. Не спеша я вышел на берег Чадана. С наслаждением хлебнул свежего прохладного воздуха, умылся прозрачной водой» ${ }^{4}$.

В партийном фонде 50-1-116 хранится рукопись дополнительных воспоминаний к главе «Шушенское», датированная 1969 г. 34 листа напечатаны на машинке, последующие - 35-56 написаны от руки) (ГА РТ, ф.П.-50, оп. 1, д. 116, л. 1-56).

Видно, что данная рукопись предназначалась для очередной главы романа «Слово арата». В тексте третьей книги «Новая Тува» трилогии «Слово арата», изданной в 1964 г. в Тувинском книжном издательстве на тувинском языке имеется первая глава «Село Шушенское» (Тока, 1964: 5), а в русских изданиях такой главы нет, имеется глава «За Большим порогом», где действие романа разворачивается

\footnotetext{
1 Там же. С. 299.

2 Там же. С. 361.

3 Там же. С. 308.

4 Там же.
} 
в селе Шушенском: «И снова - от Шушенского плеса - вниз по реке. Тихо, величаво катился УлугХем, становясь все шире и шире» (Тока, 1973: 222). Глава «За Большим порогом» издания 1973 года (издательства «Современник», г. Москва) начинается с воспоминаний Салчака Токи о поездке в Москву, на учебу в КУТВ. Молодые тувинцы, будущие студенты ехали мимо села Шушенское и узнали от местного жителя Павла Медведева информацию о вожде мирового пролетариата - В. И. Ленине.

Действие воспоминаний сразу на этом прерывается и рассказывается о том, что молодые ребята попадают на железнодорожную станцию «Удельная» (в издании 1973 г. станция называется «Малая Удельная»), на дачу № 5, под «жесткий» режим, приближенный к армейскому. Из рукописи видно, что слово «жесткий» было добавлено собственноручно автором.

На их пути встречаются люди разных национальностей: корейцы, монголы и выходцы из Африки «как уголь черных, кудрявых с белыми зубами людей» (ГА РТ, ф.п.-50, оп. 1, д. 116, л. 5). Сам Тока быстро приобщился к коллективной, коммунальной жизни. Стал старшим тувинской группы, вскоре стал инструктором (собственноручно выделил, вычеркнув из предложения слово «руководить»). В опубликованном тексте этот эпизод представлен так:

«Вскоре я стал инструктором, проводил утреннюю зарядку, вошел в состав редколлегии стенной газеты» (там же: л. 1).
«Ну, как, Тока, готовы? - спросил незнакомый мне человек, войдя в комнату. На нем был белый чесучовый костюм, белая фуражка и густо натертые зубным порошком брезентовые туфли. Заметив мое недоумение, он сказал:

- Я из деканата. Вот что, товарищ Тока. Ты назначаешься старостой тувинских студентов. Ясно?» ${ }^{1}$.

\section{В опубликованном тексте ни слова о том, что Тока стал также инструктором.}

Далее в рукописи описывается эпизод из летнего отдыха тувинских студентов на берегу Черного моря, в Туапсе: «Мы мало разбирались в географии. Не только абсолютно не знали, что такое море, кроме рек и озер, в частности не знали, что океаны и моря бывают разными, в разных частях света и имеют свое название...» (ГА РТ, ф.п.-50, оп. 1, д. 116, л. 9).

Море для многих тувинцев оказалось диковинкой. Долго не могли привыкнуть к соленой воде. Затем последовало путешествие в Новоафонский монастырь. В Новом Афоне впервые автору-повествователю удалось попробовать виноградное вино. Он описывает нелицеприятную ситуацию с распитием вина:

«И проснулся на нарах, по рукам и ногам связанный. Товарищи говорят - Вы безобразничали, вчера напились до бессознания и устроили дебош, изгадили постель и замарали “славу нашей тувинской группы” и т. д.» (там же: л. 10).

«Проснулся я на нарах. Товарищи глаза прячут. Ну и напились мы вчера. Опозорили всю нашу тувинскую группу» ${ }^{2}$.

Текст от рукописи отличается тем, что действие описано коротко, сухо, без подробностей произошедшего.

Молодой Тока во время товарищеского суда оправдывался, что он из отдаленного уголка Тувы, с оленеводческого хошуна, из Тоджи: «Тоджинские оленеводы не только от вина, но и с кусочка сыра пьянеют, а с бутылки вина на двоих, конечно стали пьяными» (ГА РТ, ф.п.-50, оп. 1, д. 116, л. 11). В тексте 1973 г. этот эпизод представлен в диалогической форме:

- Я, например, из самого отдаленного уголка Тувы, из оленеводческого хошуна, из Тоджи - начал убеждать я» (Тока, 1973: 252)

\footnotetext{
${ }^{1}$ Там же. С. 242.

2 Там же. С. 252.

${ }^{3}$ О происхождении Салчака Калбакхорековича Токи пишет М. С. Байыр-оол (Байыр-оол, 2009: Электр. ресурс). В своей автобиографии 1941 г. сначала С. К. Тока писал о том, что родился в Каа-Хемском кожууне, но «на самом деле он родился в живописном уголке Тоджи на берегу озера Моон-Холь в 1896 г. (там же: 292). Почти за год до ухода из жизни, летом 1972 г. С. К. Тока побывал на озере Моон-Холь. Своим спутникам он указал на вековую лиственницу и сказал: «Мать меня родила под этой могучей лиственницей» (там же). Когда его не стало, по указанию партийных властей в Моон-Холь были отправлены три вертолета, которые набрали полные
} 
Далее по рукописи Тока и его товарищи-тувинцы просили их не отчислять из КУТВ, обещали впредь не допускать такую ситуацию: «Это «событие» для меня было первым и последним. Все четыре года учебы в КУТВе были большой школой в учебе и жизни. Я все время благодарен и благодарю товарищей, которые вовремя поправили меня, дали правильный путь, по которому я шел много лет (ГА РТ, ф.п.-50, оп. 1, д. 116, л. 13).

Этот эпизод в тексте романа-трилогии «Слово арата» излагается следующим образом: «Это “событие” было в самом деле первым и последним. За все годы учебы в КУТВе ни мне, ни оставшимся в университете друзьям-тувинцам не пришлось больше быть в роли “подсудимых” (Тока, 1973: 253).

Таким образом, текстологическая и общекультурная ценность разных отрывков романа «Слово арата» очевидна, в собрании ГА РТ эти рукописи датируются 1947-1964 гг. Темой отдельного текстологического исследования послужит рукопись повести «Араттың сөзү» («Слово арата») на тувинском языке, написанная от руки. Сравнение разных отрывков романа с опубликованным материалом и их сопоставление позволяет в известной мере постигнуть секреты творческой лаборатории писателя.

\section{Заключение}

Собрание литературных текстов Салчака Тока в фондах Государственного архива Республики Тыва представляет собой чрезвычайно интересные тексты, сравнение и сопоставление которых с изданными впоследствии текстами позволяют проследить историю создания произведений, а также изменения в творческих приемах писателя, в эволюции его творчества. Таковы, например, фрагменты, описывающие появление охотника Улур-Херела в рассказе «Охота на волков», а также ряд различных эпизодов, непосредственно связанных с романом «Слово арата», где обнаруживаются разночтения. Многие фрагменты рукописи романа «Слово арата» разнятся с окончательной редакцией многочисленных изданий.

Изучение архивных рукописей позволяет проследить рождение незабываемых образов и персонажей С. Тока, глубже понять особенности сюжетостроения, композицию, почувствовать часто ускользающие при чтении тончайшие нюансы, столь необходимые для объективной интерпретации произведений.

Можно надеяться, что изучение рукописного литературного наследия Салчака Тока, введение этих материалов в научный оборот поможет в осуществлении полного издания собраний сочинений на русском и тувинском языках С. К. Токи с научными комментариями.

\section{СПИСОК ЛИТЕРАТУРЫ}

Байыр-оол, М. С. (2009) Сын своего времени [Электронный ресурс] // Новые исследования Тувы. № 1-2. URL: https://nit.tuva.asia/nit/article/view/672 (дата обращения: 22.01.2020).

Донгак, У. А. (2015) В поисках трех знаний. Документальная проза С. К. Тока // Салчак Тока / Н. М. Моллеров, А. К. Канзай, Г. Ч. Ширшин и др. М. : Слово/Slovo. 544 с. С. 372-399.

Калзан, А. К. (1958) Тувинская драматургия периода ТНР: о пьесах С. К. Тока «Төңгүр-оол», «Женщина», «УзунКара и Семис-Кара» // Ученые записки ТНИИЯЛИ. Кызыл : б. и. Вып. 6. С.115-136.

Комбу, С. С. (2012) Из истории издания романа С. Тока «Слово арата» // Девятые Макушинские чтения: материалы научн. конф. (15-16 мая 2012 г., Барнаул) / отв. ред. Е. Н. Савенко. Новосибирск : б. и. 372 с. С. 158-160.

Красильникова Е. И., Вальдман И. А. (2020) Власть и традиционная культура региона в динамике журнальных репрезентаций: Тува на страницах журнала «Сибирские огни» (1920-е - 2010-е гг.) [Электронный ресурс] // Новые исследования Тувы. № 1. URL: https://nit.tuva.asia/nit/article/view/910 (дата обращения: 22.01.2020.). DOI: https:// www.doi.org/10.25178/ nit.2020.1.13

Кужугет, М. А (2015) Салчак Тока - драматург // Салчак Тока / Н. М. Моллеров, А. К. Канзай, Г. Ч. Ширшин и др. М. : Слово/Slovo. 544 с. С. 399-435.

Салчак, В. С. (2010) Салчак Токаның «Бөрүлерни аңнаары» деп чечен чугаазында маадырларның овур-хевириниң укталган төөгүзү» [История создания образов героев рассказа Салчака Тока «Охота на волков»] // Салчак В. Уран сөстүң ужуу [Искусного слова связующая нить]. Абакан : ООО «Кооператив “Журналист”. 144 ар. С. 48-60.

борта веток и, согласно русскому обычаю, бросали хвойные ветки по пути следования кортежа, когда хоронили

С. Тока (там же). 
Херел, А. Х. (2018) Творчество В. Кок-оола и его роль в становлении и развитии тувинской драматургии: автореф. дис. ... канд. филол. наук. М. 32 с.

Чамзо, Д. У. (2018) Фонд государственного и политического деятеля, писателя С. К. Тока в Государственном архиве Республики Тыва // Роль и значение архивов и архивных документов в сохранении исторической памяти народа: материалы региональной научно-практической конференции, посвященной 100-летию государственной архивной службы России / отв. ред. Б. В. Мунге. Кызыл: Типография КЦО «Аныяк». 124 с. С. 83-86.

Ширшин, Г. Ч. (2017) Летопись советской Тувы 1950-1960-х гг. в дневниках Салчака Тока [Электронный ресурс] // Новые исследования Тувы. № 4. URL: https://nit.tuva.asia/nit/article/view/739 (дата обращения: 22.01.2020). DOI: https://www.doi.org/10.25178/nit.2017.4.4

Дата поступления: 01.02.2020 г.

\section{REFERENCES}

Baiyr-ool, M. S. (2009) Syn svoego vremeni [The son of his own time]. The New Research of Tuva, no. 1-2 [online] Available at: https://nit.tuva.asia/nit/article/view/672 (access date: 22.01.2020). (In Russ.).

Dongak, U. A. (2015) V poiskakh trekh znanii. Dokumental'naia proza S. K. Toka [In search of three types of knowledge. Documentary prose of S. K. Toka]. In: Salchak Toka / N. M. Mollerov, A. K. Kanzai, G. Ch. Shirshin et al. Moscow, Slovo/ Slovo. 544 p. Pp. 372-399.

Kalzan, A. K. (1958) Tuvinskaia dramaturgiia perioda TNR: o p'esakh S. K. Toka «Tönggür-ool», «Zhenshchina», «UzunKara i Semis-Kara» [Tuvan dramaturgy of the TPR period: On S.K. Toka’s plays “Tengur-ool”, “Woman”, "Uzun-Kara and Semis-Kara”]. Uchenye zapiski TNIIIaLI. Kyzyl, s. n. Vol. 6. Pp.115-136. (In Russ.).

Kombu, S. S. (2012) Iz istorii izdaniia romana S. Toka «Slovo arata» [From the history of the publication of the novel “The Word of Arat” by S. Toka]. In: Deviatye Makushinskie chteniia [9th Makushin readings]: proceedings of a conference (May 15-16, 2012, Barnaul) / ed. by E. N. Savenko. Novosibirsk, s. n. 372 p. Pp. 158-160. (In Russ.).

Krasilnikova,E. I. and Valdman, I. A. (2020) Power and the traditional culture of a region in the dynamics of magazine representations: Tuva on the pages of the Sibirskie Ogni magazine (1920s - 2010s). The New Research of Tuva, no. 1 [online] Available at: https://nit.tuva.asia/nit/article/view/910 (access date: 22.01.2020). (In Russ.). DOI: 10.25178/nit.2020.1.13

Kuzhuget, M. A (2015) Salchak Toka - dramaturg [Salchak Toka, a playwright]. In: Salchak Toka / N. M. Mollerov, A. K. Kanzai, G. Ch. Shirshin et al. Moscow, Slovo/Slovo. 544 p. Pp. 399-435. (In Russ.).

Salchak, V. S. (2010) Salchak Tokanyng «Börülerni angnaary» dep chechen chugaazynda maadyrlarnyng ovurkhevirining uktalgan töögüzü» [The history of the characters of the story by Salchak Toka "Hunting for wolves"]. In: Salchak V. Uran söstüng uzhuu [Skillful words connecting thread]. Abakan, Kooperativ “Zhurnalist”. 144 p. Pp. 48-60. (In Tuv.).

Kherel, A. Kh. (2018) Tvorchestvo V. Kok-oola i ego rol' v stanovlenii i razvitii tuvinskoi dramaturgii [The works by V. Kok-ool and his role in the rise and development of Tuva drama] : Thesis of Diss.... Candidate of Philology. Moscow. 32 p. (In Russ.).

Chamzo, D. U. (2018) Fond gosudarstvennogo i politicheskogo deiatelia, pisatelia S. K. Toka v Gosudarstvennom arkhive Respubliki Tyva [The archival collection of the statesman, political figure and writer S. K. Toka in the State Archives of the Republic of Tuva]. In: Rol' i znachenie arkhivov i arkhivnykh dokumentov $v$ sokhranenii istoricheskoi pamiati naroda [The role and significance of archives and archival documents in preserving the historical memory of a people] : materials of the regional conference dedicated to the 100th anniversary of the State Archival service of Russia / ed. by B. V. Munge. Kyzyl, Tipografiia KTsO «Anyiak». 124 p. Pp. 83-86. (In Russ.).

Shirshin, G. Ch. (2017) Letopis' sovetskoi Tuvy 1950-1960-kh gg. v dnevnikakh Salchaka Toka [A chronicle of the Soviet Tuva (1950s - 1960s) in the diaries of Salchak Toka]. The New Research of Tuva, no. 4 [online] Available at: https://nit.tuva. asia/nit/article/view/739 (access date: 22.01.2020). (In Russ.). DOI: 10.25178/nit.2017.4.4

Submission date: 01.02.2020. 